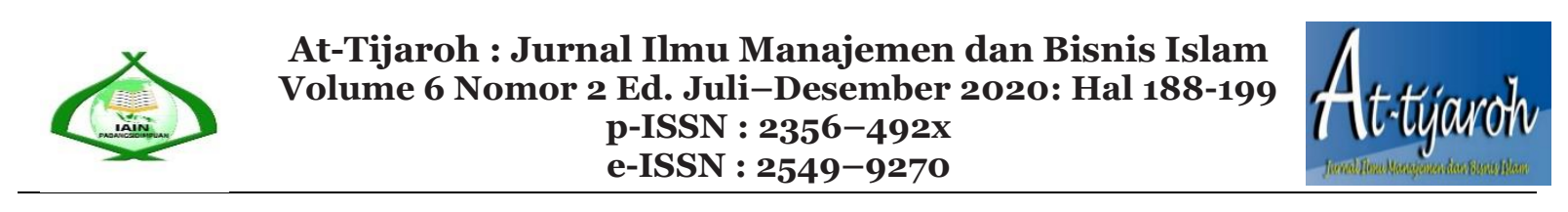

\title{
ANALISIS KUALITAS LAYANAN MOBILE JKN TERHADAP KEPUASAN PESERTA BADAN PENYELENGGARA JAMINAN SOSIAL KESEHATAN
}

\author{
Rita Komala ${ }^{1}$, Achmad Firdaus ${ }^{2}$ \\ 1,2Institut Agama Islam (IAI) Tazkia \\ 1,2Jln. Ir. H. Juanda no 78 Sentul City Bogor \\ 1 rhyeethakomala@gmail.com \\ 2achmad.firdaus@tazkia.ac.id
}

\begin{abstract}
The study aims to analyze the effect of E-Service Quality, namely the variables Reliability, Efficiency, Fulfillment, Privacy, Responsiveness, and Contact on JKN-KIS participants' satisfaction in the Social Security Organizing Agency (BPJS) Health. The study uses the method of Multiple Linear Regression with SPSS 21 software. Sample of 100 respondents. Respondents are JKN Mobile users. Research shows that the variables Reliability, Efficiency, Fulfillment, Privacy, Responsiveness, Contact simultaneously have a positive and significant effect on participant satisfaction. The study also showed that the efficiency, fulfillment, and responsiveness variables had a positive and significant effect on the satisfaction of JKN-KIS participants, and the Reliability, Privacy and Contact variables had a positive but not significant effect on participant satisfaction.
\end{abstract}

Keywords: Quality of Electronic Services, JKN Mobile, Customer Satisfaction

\begin{abstract}
Abstrak
Penelitian bertujuan untuk menganalisis pengaruh E-Service Quality yaitu variabel Reliability, Efficiency, Fulfillment, Privacy, Responsiveness, dan Contact terhadap kepuasan peserta JKNKIS Badan Penyelenggara Jaminan Sosial (BPJS) Kesehatan. Penelitian menggunakan metode Regresi Linier Berganda dengan software SPSS 21. Sampel sebanyak 100 responden. Responden adalah pengguna Mobile JKN. Penelitian menunjukkan bahwa variabel Reliability, Efficiency, Fulfillment, Privacy, Responsiveness, Contact secara simultan berpengaruh positif dan signifikan terhadap kepuasan peserta. Penelitian juga menunjukkan bahwa secara persial variabel efficiency, fulfillment, dan responsiveness berpengaruh positif dan signifikan terhadap kepuasan peserta JKN-KIS, dan variabel Reliability, Privacy, dan Contact berpengaruh positif tetapi tidak signifikan terhadap kepuasan peserta.
\end{abstract}

Kata Kunci: Kualitas Layanan Elektronik, Mobile JKN, Kepuasan Pelanggan 


\section{PENDAHULUAN}

Dalam pasal 6 ayat (1) Undang-Undang Republik Indonesia No. 24 Tahun 2011 tentang BPJS (Badan Penyelenggara Jaminan Sosial) disebutkan bahwa BPJS Kesehatan merupakan badan hukum publik yang dibentuk untuk menyelenggarakan program jaminan kesehatan Nasional (JKN). Selanjutnya pasal 14 menyebutkan bahwa peserta BPJS adalah setiap individu, dan untuk orang asing yang telah bekerja di Indonesia paling singkat 6 (enam) bulan wajib menjadi peserta program jaminan sosial. Dalam hal ini, BPJS Kesehatan telah memiliki program kesehatan yang disebut Program Jaminan Kesehatan Nasional - Kartu Indonesia Sehat (JKN-KIS).

Saat ini, jumlah peserta program JKN-KIS per 1 Januari 2019 tercatat sebanyak 215.784.340 jiwa. Jumlah tersebut mengalami kenaikan sebesar 3,8\% dari tahun 2018, yaitu sebanyak 207.834.315 jiwa per 31 Desember 2018. Peserta JKN-KIS memiliki enam golongan jenis kepesertaan, yaitu Penerima Bantuan Iuran-APBN (PBI-APBN) sebayak 96.643.963 jiwa, Penerima Bantuan Iuran- APBD (PBI-APBD) sebanyak 33.149.203 jiwa, Pekerja Penerima Upah-Pegawai Negeri (PPU-PN) sebanyak 17.206.407, Pekerja Penerima Upah-Badan Usaha (PPU-BU) sebanyak 32.697.826, Pekerja Bukan Penerima Upah (PBPU)-Pekerja Mandiri sebanyak 30.948.016, dan Bukan Pekerja sebanya 5.138.925 (BPJS Kesehatan, n.d.-a).

Saat ini, perkembangan teknologi informasi yang pesat mendorong BPJS Kesehatan untuk melakukan inovasi digital. Salah satunya, sebagai solusi keluhan antrian panjang di kantor BPJS Kesehatan. Pada 15 November 2017 BPJS Kesehatan resmikan aplikasi yang bernama "Mobile JKN". Mobile JKN hadir sebagai salah satu sarana untuk mempermudah kebutuhan peserta dan calon peserta JKN-KIS. Pada dasarnya, Mobile JKN adalah kegiatan administratif yang biasa dilakukan di kantor cabang atau fasilitas kesehatan (BPJS Kesehatan, n.d.-b).

Kehadiran Mobile JKN diharapkan mampu memberi kemudahan akses serta pelayanan yang lebih optimal bagi peserta. Dengan Mobile JKN, peserta dapat lebih mudah mengakses beragam informasi terkait program JKN-KIS dengan mudah dan cepat, serta dapat digunakan kapanpun dan dimanapun. Selain itu, Mobile JKN memiliki empat belas fitur yang dapat mempermudah peserta dan calon peserta JKN-KIS, yaitu fitur peserta, ubah data peserta, kartu digital peserta, pendaftaran peserta, premi, pembayaran, riwayat pembayaran, histori pelayanan peserta, cek Virtual Account (VA), riwayat pelayanan, pendaftaran pelayanan, skrining kesehatan, info JKN, dan lokasi (BPJS Kesehatan, n.d.-a)

Sosialisasi Mobile JKN telah dilaksanakan diseluruh kantor cabang BPJS Kesehatan. Sosialisasi dilaksanakan baik melalui perorangan, Badan Usaha, atau instansi pemerintah (Saleh, 2018). Selanjutnya, sejak peresmian launcing Mobile JKN kini jumlah peserta yang telah mengunduh Mobile JKN pun meningkat setiap tahunnya. Diharapkan dengan hadirnya 


\section{0 |Analisis Kualitas Layanan Mobile JKN Terhadap Kepuasan Peserta Badan Penyelenggara Jaminan Sosial (BPJS) Kesehatan}

Mobile JKN akan meminimalisir dan mengatasi antrian panjang panjang di kantor-kantor BPJS Kesehatan.

Tabel 1

Jumlah Pengguna Mobile JKN periode 2016-2019

\begin{tabular}{lc}
\hline Periode & Jumlah \\
\hline Juni-Desember 2016 & 229.018 \\
Januari-Desember 2017 & 878.402 \\
Januari-Desember 2018 & 2.294 .388 \\
Januari-Februari 2019 & 481.164 \\
\hline TOTAL & $\mathbf{3 . 8 8 2 . 9 7 2}$ \\
\hline
\end{tabular}

Sumber: BPJS Kesehatan, 2019

Selanjutnya, sebagai fasilitas yang dilakukan dengan self-service, BPJS Kesehatan haruslah melakukan pemantauan dan pengevaluasian mengenai kualitas Jasa layanan Mobile JKN, dikarenakan kepuasan pelanggan memiliki hubungan erat dengan kualitas jasa (Akbar \& Parvez, 2009). Jasa merupakan suatu manfaat yang diberikan oleh satu pihak kepada pihak lain. Sifat jasa yaitu tidak berwujud dan tidak berunsur kepemilikan. Dengan demikian, kualitas jasa adalah bagian yang sangat penting untuk lebih diperhatikan oleh semua perusahaan jasa. Tingkat kualitas jasa dapat diperoleh melalui konsistensi dalam pemberian pelayanan kepada pelanggan. Dengan demikian, akan terciptanya kepuasan yang dirasakan oleh pelanggan pengguna jasa (Parasuraman et al., 2005).

Kepuasan (Satisfaction) adalah suatu perasaan baik senang ataupun kecewa yang datang kerena membandingkan kinerja suatu produk yang diharapkan sesuai dengan ekspektasi (Tjiptono, 2000). Perusahaan yang berorientasi pada pelanggan (customeroriented), kepuasan pelanggan adalah tujuan dan juga sarana dalam pemasaran. Perusahaan harus lebih baik dalam memperhatikan kepuasan pelanggan, karena jika kurang memperhatikan kepuasan pelanggan, pelanggan dapat menyebarkan berita baik atau buruk kepada seluruh dunia melalui media internet atau sejenisnya (Kotler \& Keller, 2009).

Untuk mengetahui tingkat kepuasan pelanggan melalui survei kepuasan pelanggan, secara konseptualkan pengukuran kepuasan pelanggan yaitu sebagai pertama, Kesesuaian harapan merupakan kesamaan antara kinerja produk yang diharapkan sesuai dengan ekspektasi pelanggan dan realita yang didapatkan dan dirasakan oleh pelanggan. Kedua, Minat berkunjung kembali merupakan suatu keinginan pelanggan untuk berkunjung kembali atau keinginan untuk membeli ulang terhadap produk tersebut. Ketiga, Kesediaan merekomendasikan merupakan kesediaan pelanggan untuk memberitahu kepada yang lain, atau merekomendasikan atau memberi saran terhadap produk tersebut kepada orang lain (Tjiptono, 2014). 
Dalam konteks Mobile Application, yang harus diperhatikan oleh perusahaan jasa yaitu Electronic Service Quality (E-S-QUAL). E-S-QUAL didefinisikan sebagai seberapa jauh suatu situs mampu memberikan fasilitas yang optimal dalam memenuhi kebutuhan pelanggan, seperti belanja, pembelian dan pengiriman produk, layanan secara efisien, ketersediaan dan kelengkapan informasi, serta kemudahan bertransaksi akan mempengaruhi minat dan kepercayaan pelanggan dalam penggunaan jasa (Parasuraman et al., 2005)

Tujuh dimensi E-Service Quality sebagai pengukur kualitas jasa online, yaitu 1) Efficiency, mengacu kepada kemudahan bagi pelanggan dalam pengaksesan suatu website, kemudahan dalam pencarian produk yang dibutuhkan dan kemudahan mendapatkan informasi tentang produk tersebut, serta meninggalkan situs bersangkutan dengan upaya minimal. 2) Reliability (kehandalan) berkaitan dengan ketersediaan situs, dan menjalankan fungsinya dengan baik. 3) Fulfillment (pemenuhan) mengacu kepada akurasi janji pelayanan, ketersediaan stok produk dan pengiriman yang tepat waktu, 4) Privacy (kerahasiaan) berkenaan dengan jaminan terkait data pribadi seseorang yang tidak akan diberikan kepada pihak lain manapun dan bahwa informasi kartu pelanggan terjamin keamanannya. 5) Responsivenss (ketanggapan) mengukur kecepatan respon dalam pemberian informasi kepada pelanggan ketika bermasalah dan menjawab pertanyaan dari pelanggan. 6) Compensation (compensasi) meliputi pengembalian uang, biaya pengiriman dan biaya penanganan produk. 7) Contact (kontak) yaitu memberikan kemudahan berbicara dengan staf layanan pelanggan baik secara online atau melalui telepon (Zeithaml et al., 2002).

Berdasarkan pemaparan latar belakang di atas, rumusan penelitian dari masalah tersebut adalah bagaimana Pengaruh Variabel E-Service Quality yaitu reliability, efficiency, fulfillment, privacy, responsiveness, contact terhadap Kepuasan Peserta JKN-KIS BPJS Kesehatan. Dengan tujuan penelitian yaitu Mengetahui bagaimana Pengaruh variabel reliability, efficiency, fulfillment, privacy, responsiveness dan contact secara simultan terhadap Kepuasan Peserta JKN-KIS BPJS Kesehatan. Penelitian merujuk kepada dua penelitian terdahulu yaitu (Parasuraman et al., 2005) yang membahas mengenai E-Service Quality yaitu E-S-QUAL: A Multiple-Item Scale for Assessing Electronic Service Quality dan penelitian (Iswanca et al., 2016) yang membahas mengenai pengaruh e-service quality aplikasi Garuda Indonesia terhadap customer satisfaction Garuda Indonesia. Yang membedakan dengan penelitian sebelumnya yaitu dari segi objek, segi metode pengambilan data, dan segi lokasi. Penelitian berfokus pada kepuasan peserta JKN-KIS BPJS Kesehatan dengan menggunakan E-S-QUAL. Kemudian perbedaan lainnya, penelitian ini menggunakan analisis regresi linier berganda dan variabel yang digunakan yaitu Reliability, Efficiency, Fulfillment, privacy, Responsiveness, Contact. Pengambilan variabel tersebut merujuk kepada dua jurnal acuan. Berikut Kerangka Pemikiran dalam penelitian: 


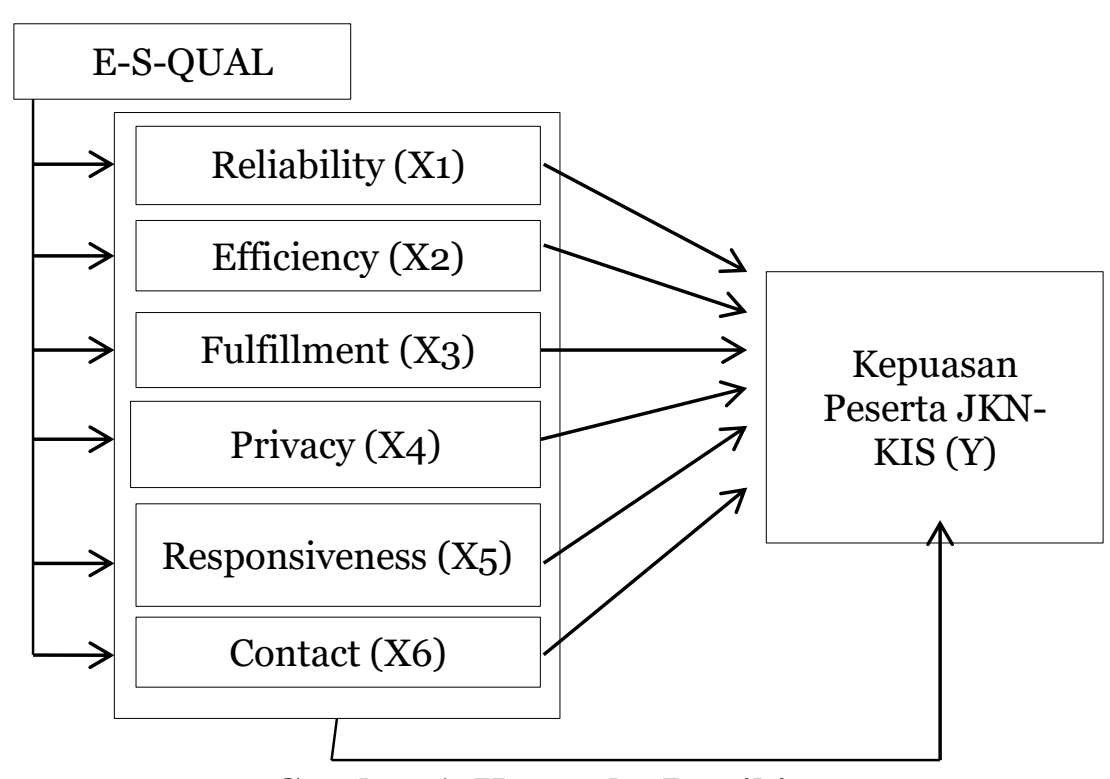

Gambar 1. Kerangka Pemikiran

Pada dasarnya banyak sekali penelitian yang mengkaji hubungan antara kualitas layanan dengan kepuasan peserta. Diantaranya adalah pengaruh $e$-service quality aplikasi Garuda Indonesia terhadap customer satisfaction Garuda Indonesia. Hasilnya menunjukkan bahwa secara simultan e-service quality berpengaruh signifikan terhadap customer satisfaction sebesar 49,4\%. Dan secara persial menunjukkan bahwa yang berpengaruh signifikan yaitu web design, reliability, system availability, responsiveness, empathy sedangkan variabel easy of use dan privacy tidak berpengaruh signifikan terhadap customer satisfaction Garuda Indonesia (Iswanca et al., 2016). Selanjutnya penelitian tentang pengaruh kualitas layanan mobile banking terhadap kepuasan nasabah Bank BCA di Kota Bandung (Febrianta \& Indrawati, 2016). Hasilnya menunjukkan bahwa variabel Assurance and Security

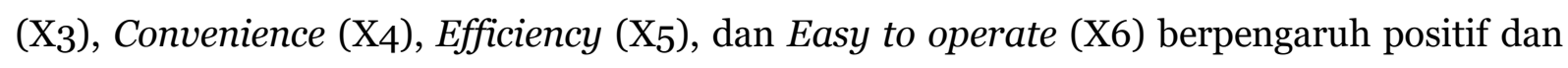
signifikan terhadap kepuasan nasabah sedangkan variabel Reliability (X1) dan Responsiveness (X2) tidak berpengaruh signifikan terhadap kepuasan nasabah. (Chesanti \& Setyorini, n.d.) menganalisis pengaruh E-Service Quality terhadap kepuasan pelanggan sebagai pengguna aplikasi PLN Mobile. Hasilnya menunjukkan bahwa e-service quality berpengaruh sebesar 49,9\% terhadap kepuasan pelanggan dan 50,1\% sisanya dipengaruhi oleh variabel lain. (Safira et al., 2017) menganalisis kualitas layanan website Bukalapak terhadap kepuasan pengguna menggunakan E-S-QUAL. Hasilnya menunjukkan bahwa variabel efficiency, system availability, privacy, dan responsiveness memiliki pengaruh yang signifikan terhadap kepuasan pengguna website Bukalapak sedangkan variabel compensation and contact tidak memiliki pengaruh yang signifikan. (Widiani \& Abdullah, 2018) menganalisis kualitas pelayanan E-Government melalui aplikasi E-Filing Kantor Pelayanan 
Pajak Pratama Bandung Cibeunying terhadap kepuasan pengguna aplikasi. Hasil penelitian menunjukkan bahwa variabel kualitas pelayanan E-Government memberikan pengaruh sebesar 70,5\% terhadap kepuasan pengguna aplikasi. Sedangkan, sisanya sebesar 29,5\% disebabkan oleh variabel lain atau faktor lain diluar penelitian ini. Berdasarkan hasil-hasil dari penelitian tersebut, maka hipotesis yang diajukan adalah sebagai berikut:

H1: Reliability berpengaruh terhadap kepuasan peserta JKN-KIS.

H2: Efficiency berpengaruh terhadap kepuasan peserta JKN-KIS.

H3: Fulfillment berpengaruh terhadap kepuasan peserta JKN-KIS.

H4: Privacy berpengaruh terhadap kepuasan peserta JKN-KIS.

$\mathrm{H}_{5}$ : Responsiveness berpengaruh terhadap kepuasan peserta JKN-KIS.

H6: Contact berpengaruh terhadap kepuasan peserta JKN-KIS.

H7: Reliability, Efficiency, Fulfillment, Privacy, Responsiveness, dan Contact berpengaruh signifikan terhadap kepuasan peserta JKN-KIS.

\section{METODE PENELITIAN}

Penelitian menggunakan Purposive Sampling sebagai teknik pengambilan sampel dengan kriteria pertama, pria atau wanita dengan minimal usia 18 tahun, dimana usia tersebut diasumsikan bahwa responden sudah cukup mengerti dan dapat menanggapi pertanyaanpertanyaan dari kuesioner dengan baik. Kedua, peserta yang telah mendownload dan menggunakan aplikasi Mobile JKN. Jumlah responden sebanyak 100 responden yang dihitung menggunakan rumus slovin. Teknik analisis data menggunakan Regresi Linier Berganda.

\section{HASIL DAN PEMBAHASAN}

Berdasarkan hasil dari uji validitas, penelitian memiliki nilai $r$ tabel yaitu 0,198 yang didapat dari rumus $\mathrm{Df}=\mathrm{n}-2(100-2=98)$ dengan menggunakan tingkat signifikansi yaitu 5\%. Setelah pengujian validitas menggunakan SPSS 21, terlihat bahwa hasil dari $r$ hitung pada 22 item pertanyaan yang diuji memiliki nilai $r$ hitung $>0,198$, artinya $r$ hitung $>r$ tabel. Maka dapat disimpulkan bahwa 22 item pertanyaan pada penelitian ini dinyatakan valid.

Hasil uji reliabilitas, perolehan nilai Cronbach Alpha untuk 22 item pertanyaan meliputi variabel dependen dan independen lebih dari o,6. Maka dari itu dapat disimpulkan bahwa kuesioner dalam penelitian ini dinyatakan reliabel.

Selanjutnya, klasifikasi responden berdasarkan jenis kelamin laki-laki sebanyak 59 responden (59\%) dan klasifikasi responden berdasarkan jenis kelamin perempuan sebanyak 41 responden (41\%). Dan klasifikasi responden berdasarkan rentang usia yaitu 17-26 tahun terdapat sebanyak 37 responden (37\%) dan rentang umur 27-36 tahun sebanyak 36 responden (36\%), rentang umur 37-46 tahun sebanyak 16 responden (16\%), rentang usia 47-56 tahun 


\section{4 |Analisis Kualitas Layanan Mobile JKN Terhadap Kepuasan Peserta Badan Penyelenggara Jaminan Sosial (BPJS) Kesehatan}

sebanyak 9 responden (9\%), dan terakhir rentang umur lebih dari 56 tahun sebanyak 2 responden $(2 \%)$.

Klasifikasi jenis pekerjaan pada pegawai negeri sebanyak 10 responden (10\%), pegawai swasta sebanyak 34 responden (34\%), mahasiswa sebanyak 16 responden (16\%), pelajar sebanyak 1 responden (1\%), dan lainnya sebanyak 39 responden (39\%). Dan klasifikasi responden berdasarkan alasan responden menggunakan aplikasi Mobile JKN, didominasi dengan alasan mempermudah semua urusan terkait BPJS Kesehatan yaitu dengan persentase sebesar 47\% (47 responden), selanjutnya responden dengan alasan lebih efisien, tidak harus mengantri dan menunggu lama sebanyak 29 responden (29\%), selanjutnya responden dengan alasan dapat dilakukan kapan saja dan dimana saja sebanyak 19 responden (19\%), selanjutnya responden dengan alasan lainnya sebanyak 5 responden (5\%), namun tidak terdapat responden yang memilih alasan melakukan pengaduan lebih mudah.

Hasil pengujian regresi linier berganda tertulis bahwa Perolehan nilai konstanta bo $=$ $-0,575$, koefisien regresi b1 $=0,079, \mathrm{~b} 2=0,594, \mathrm{~b} 3=0,452, \mathrm{~b} 4=0,026, \mathrm{~b} 5=0,599, \mathrm{~b} 6=0,214$. Maka persamaan regresi linier berganda adalah $\mathrm{Y}=-0,575+0,079(\mathrm{rlb})+0,594(\mathrm{eff})+0,452$ (fulf) $+0,026$ (priv) + 0,599 (resp) + 0,214 (cont) $+0,279$ (e)

Konstanta bernilai negatif, yaitu -0,575 menunjukkan bahwa jika tidak terdapat variabel reliabilitas (X1), efficiency (X2), fulfillment ( $\left.\mathrm{X}_{3}\right)$, privacy $\left(\mathrm{X}_{4}\right)$, responsiveness $\left(\mathrm{X}_{5}\right)$, dan contact (X6) maka besarnya kepuasan peserta yang diperoleh menurun sebesar 0,575. Artinya nilai o,575 tersebut adalah nilai ketika nilai variabel reliability, efficiency, fulfillment, privacy, responsiveness dan contact konstan.

Selanjutnya, koefisien reliability memiliki nilai positif yaitu sebesar 0,079 dan nilai signifikansi sebesar $0,615=0,615>0,05$ atau Ho diterima. Artinya reliability tidak berpengaruh terhadap kepuasan peserta. Berdasarkan hasil uji persial, Reliability memperoleh nilai $\mathrm{t} 1=0,505, \mathrm{db}=93$, Signifikansi $=0,615$. Dengan demikian, diketahui bahwa $\mathrm{t} 1<\mathrm{t}$ tabel . $(0,505<1,985)$ dan Signifikansi 0,615 > 0,05. Artinya variabel Reliability tidak berpengaruh terhadap kepuasan peserta. Maka hipotesis H1 ditolak. Hasil penelitian bertolak belakang dengan Febrianta dan Indrawati, (2016) yang Menganalisis pengaruh kualitas layanan mobile banking terhadap kepuasan nasabah Bank BCA di kota Bandung. dan penelitian Asadpoor dan Abolfazli, (2017) yang menganalisis "Effect of Electronic Service Quality on Customer Satisfaction and Loyalty Saderat Bank's Customers". Kedua penelitian terdahulu tersebut menyatakan bahwa reliability (kehandalan) berpengaruh positif dan signifikan terhadap kepuasan peserta. Variabel reliability memiliki nilai indeks jawaban responden sebesar 3,38 (Sangat tinggi) karena Mobile JKN telah berfungsi dengan baik dan akurat, namun karena seringnya melakukan update aplikasi yang mengakibatkan peserta tidak dapat mengakses aplikasi dalam waktu yang cukup lama, oleh karenanya hal tersebut belum memenuhi ekspektasi peserta dan perlu ditingkatkan. 
Nilai koefisien efficiency memiliki nilai positif yaitu sebesar 0,594 dan nilai signifikansi sebesar 0,000 < 0,05 atau Ho ditolak. Artinya variabel efficiency memiliki pengaruh positif dan signifikan terhadap kepuasan peserta. Jika efficiency meningkat satu satuan maka kepuasan peserta juga akan meningkat sebesar 0,594. Berdasarkan hasil uji persial, Efficiency memperoleh nilai t2 $=4,032, d b=93$, Signifikansi $=0,000$. Dengan demikian, diketahui bahwa t2 > t tabel (4,032 > 1,985) dan Signifikansi 0,000 < 0,05. Dengan ini menunjukkan bahwa variabel Efficiency berpengaruh positif dan signifikan terhadap variabel kepuasan peserta. Maka hipotesis $\mathrm{H} 2$ diterima. Hasil penelitian relevan dengan penelitian yaitu Febrianta dan Indrawati, (2016) yang Menganalisis pengaruh kualitas layanan mobile banking terhadap kepuasan nasabah Bank BCA di kota Bandung dan penelitian (Safira et al., 2017) menganalisis kualitas layanan website Bukalapak terhadap kepuasan pengguna menggunakan E-S-QUAL. Kedua penelitian terdahulu menyatakan bahwa efficiency memiliki pengaruh positif dan signifikan terhadap kepuasan peserta. Efficiency mengacu kepada kemudahan pelanggan dalam mengakses aplikasi, mencari produk yang diinginkan dan informasi yang berkaitan dengan produk tersebut serta meninggalkan situs bersangkutan dengan upaya minimal. Dengan hasil nilai indeks jawaban responden pada variabel efficiency sebesar 3,30 (sangat tinggi). Hal ini menunjukkan bahwa proses login Mobile JKN mudah dan cepat, Mobile JKN memberikan beragam fitur yang mempermudah urusan dan kebutuhan peserta, Mobile JKN didesign dengan menarik dan informatif sehingga peserta tidak sulit dalam menggunakannya memberikan tingkat kepuasan yang tinggi karena memenuhi ekspektasi peserta JKN-KIS.

Nilai koefisien fulfillment memiliki nilai positif yaitu sebesar 0,452 dan nilai signifikansi sebesar 0,070 = 0,070 < 0,05 atau Ho ditolak. Artinya variabel fulfillment tidak pengaruh positif dan signifikan terhadap kepuasan peserta. Jika fulfillment meningkat satu satuan maka kepuasan peserta juga akan meningkat sebesar 0,452. Berdasarkan hasil uji persial, fulfillment memperoleh nilai $\mathrm{t}_{3}=1,832, \mathrm{db}=93$, Signifikansi $=0,070$. Dengan demikian, diketahui bahwa $\mathrm{t} 3<\mathrm{t}$ tabel $(1,832<1,985)$ dan Signifikansi 0,070 < 0,05. Dengan ini menunjukkan bahwa variabel fulfillment tidak pengaruh terhadap kepuasan peserta pada tingkat signifikan 0,05, namun berpengaruh terhadap kepuasan peserta pada tingkat signifikansi 0,10. Maka hipotesis $\mathrm{H}_{3}$ diterima. Hasil penelitian relevan dengan penelitian (Chesanti \& Setyorini, n.d.) yang menganalisis pengaruh E-Service Quality terhadap kepuasan pelanggan sebagai pengguna aplikasi PLN Mobile menyatakan bahwa fulfillment berpengaruh positif signifikan terhadap kepuasan peserta JKN-KIS, dan penelitian ini bertolak belakang dengan penelitian (Safira et al., 2017) menganalisis kualitas layanan website Bukalapak terhadap kepuasan pengguna menggunakan E-S-QUAL yang menyatakan bahwa fulfillment tidak berpengaruh terhadap kepuasan peserta. Hasil nilai indeks jawaban responden pada variabel fulfillment sebesar 3,33 (sangat tinggi). Hal ini menunjukkan bahwa kepuasan peserta 


\section{6 |Analisis Kualitas Layanan Mobile JKN Terhadap Kepuasan Peserta Badan Penyelenggara Jaminan Sosial (BPJS) Kesehatan}

JKN-KIS dipengaruhi karena Mobile JKN memberikan informasi yang akurat mengenai semua fitur dan manfaat yang didapat oleh peserta, dan semua fitur yang ada dalam Mobile $J K N$ tersedia dalam 24 Jam.

Nilai koefisien privacy memiliki nilai positif yaitu sebesar 0,026 dan nilai signifikansi sebesar 0,799 = 0,799 > 0,05 atau Ho diterima. Berdasarkan hasil uji persial, Privacy memperoleh nilai $\mathrm{t}_{4}=0,255, \mathrm{db}=93$, Signifikansi $=0,799$. Dengan demikian, diketahui bahwa $44<$ tabel $(0,255<1,985)$ dan Signifikansi 0,799 > 0,05. Dengan ini menunjukkan bahwa variabel Privacy tidak berpengaruh terhadap kepuasan peserta. Maka hipotesis $\mathrm{H}_{4}$ ditolak. Hasil penelitian relevan dengan penelitian (Iswanca et al., 2016) menganalisis pengaruh e-service quality aplikasi Garuda Indonesia terhadap customer satisfaction Garuda Indonesia yang menyatakan bahwa privacy tidak berpengaruh terhadap kepuasan peserta. Dan hasil penelitian ini bertolak belakang dengan penelitian Safira et al., (2017) menganalisis kualitas layanan website Bukalapak terhadap kepuasan pengguna menggunakan E-S-QUAL yang menyatakan bahwa privacy berpengaruh positif signifikan terhadap kepuasan peserta. Nilai indeks jawaban responden pada variabel privacy sebesar 3,33 (sangat tinggi) karena peserta JKN-KIS sejauh ini merasa aman karena terdapat fitur password saat login, konfirmasi dan token yang dikirimkan via email saat peserta merubah data pribadi. Namun hal ini tidak berpengaruh secara signifikan terhadap kepuasan peserta karena melihat dari koefisien yang bernilai positif. Dalam hal ini juga dapat ditingkatkan dari sesi ketika login aplikasi akan lebih baik lagi jika ditambahkan OTP yang dikirimkan ke email/sms disamping password dan captcha yang sudah ada untuk lebih memberikan keamanan.

Nilai koefisien responsiveness memiliki nilai positif yaitu sebesar 0,599 dan nilai signifikansi sebesar 0,000 < 0,05 atau Ho ditolak. Artinya variabel responsiveness memiliki pengaruh positif dan signifikan terhadap kepuasan peserta. Jika responsiveness meningkat satu satuan maka kepuasan peserta juga akan meningkat sebesar 0,599. Berdasarkan hasil uji persial, Responsiveness memperoleh nilai $\mathrm{t}_{5}=4.148, \mathrm{db}=93$, Signifikansi $=0,000$. Dengan demikian, diketahui bahwa t5 > t tabel $(4,148>1,985)$ dan Signifikansi 0,00o < 0,05. Dengan ini menunjukkan bahwa variabel Responsiveness berpengaruh positif dan signifikan terhadap variabel kepuasan peserta. Maka hipotesis $\mathrm{H}_{5}$ diterima. Hasil penelitian relevan dengan hasil penelitian (Iswanca et al., 2016) dan (Safira et al., 2017) menganalisis pengaruh $e$-service quality aplikasi Garuda Indonesia terhadap customer satisfaction Garuda Indonesia yang menyatakan bahwa Responsiveness berpengaruh positif dan signifikan terhadap kepuasan peserta. Dan hasil penelitian ini bertolak belakang dengan hasil penelitian (Febrianta \& Indrawati, 2016) menganalisis pengaruh kualitas layanan mobile banking terhadap kepuasan nasabah Bank BCA di kota Bandung yang menyatakan bahwa Responsiveness tidak berpengaruh terhadap kepuasan peserta. Responsiveness yaitu mengukur kecepatan respon dalam pemberian informasi kepada pelanggan ketika bermasalah dan pertanyaan dari 
pelanggan. Nilai indeks jawaban responden pada variabel responsiveness sebesar 3,19 (tinggi). Hal ini menunjukkan bahwa kepuasan peserta JKN-KIS dipengaruhi dengan kecepatan proses penanganan kebutuhan peserta, pengaduan keluhan serta penanganan keluhan lebih mudah dan cepat, dan Mobile JKN memberikan informasi lokasi fasilitas kesehatan terdekat memberikan tingkat kepuasan yang tinggi karena memenuhi ekspektasi peserta JKN-KIS.

Nilai koefisien contact memiliki nilai positif yaitu sebesar 0,214 dan nilai signifikansi sebesar 0,249 = 0,249 > 0,05 atau Ho diterima. Artinya variabel contact tidak berpengaruh terhadap kepuasan peserta. Berdasarkan hasil uji parsial, Contact memperoleh nilai t6 = 1,160, $\mathrm{db}=93$, Signifikansi $=0,249$. Dengan demikian, diketahui bahwa $\mathrm{t} 6<\mathrm{t}$ tabel $(1,160<1,985)$ dan Signifikansi 0,249 > 0,05. Dengan ini menunjukkan bahwa variabel Contact tidak berpengaruh terhadap kepuasan peserta. Maka Hipotesis H6 ditolak. Hasil penelitian bertolak belakang dengan hasil penelitian (Wijiutami \& Octavia, 2017) yang menyatakan bahwa variable contact berpengaruh positif dan signifikan terhadap kepuasan peserta. Nilai indeks jawaban responden pada variabel contact sebesar 3,40 (sangat tinggi) karena Call Center dan Care Center memberikan respon yang cepat namun menurut beberapa peserta hal tersebut tidak menyelesaikan masalah yang diajukan peserta dan akibatnya peserta masih harus pergi ke kantor BPJS terdekat. Alur untuk pengaduan via telepon, peserta akan disambungkan dengan call center 1500400 dan pengaduan tertulis akan secara otomatis masuk ke aplikasi pengaduan maksimal 3 hari kerja, keluhan akan disesuaikan dengan lokasi peserta yang nantinya akan masuk ke kantor cabang masing-masing sesuai lokasi peserta.

Variabel contact berpengaruh positif namun tidak signifikan terhadap kepuasan peserta, yang mungkin dipengaruhi oleh alur pengaduan yang panjang, oleh karenanya belum memenuhi ekspektasi peserta. Hal ini dapat lebih ditingkatkan lagi karena fitur yang sangat bermanfaat dan membantu peserta untuk tidak datang langsung ke kantor BPJS Kesehatan. Berdasarkan perhitungan $\mathrm{F}$ tabel, diperoleh hasil $\mathrm{F}$ tabel sebesar 2.20 dan $\mathrm{F}$ hitung sebesar 39,959. $\mathrm{db}=(6,94), \mathrm{Sig}=0$,ooo. Maka dapat dinyatakan bahwa $\mathrm{F}$ hitung $>$ dari F tabel. Dan Nilai Sig sebesar 0,000 < 0,05 maka dapat disimpulkan bahwa keenam variabel independen yaitu reliability, efficiency, fulfilment, privacy, responsiveness, dan contact secara simultan (bersama-sama) berpengaruh positif dan signifikan terhadap kepuasan peserta, sehingga dapat dinyatakan bahwa hipotesis $\mathrm{H} 7$ diterima. Penelitian memperoleh nilai $\mathrm{R} 2=0,721, \mathrm{~F}$ hit $=39,959, \mathrm{db}=(6,94)$, Signifikansi 0,000 < 0,05 atau Ho ditolak. Artinya variabel reliability, efficiency, fulfilment, privacy, responsiveness, dan contact dapat menjelaskan kepuasan peserta sebesar 0,721 atau $72,1 \%$ dan $27,9 \%$ lainnya dijelaskan oleh variabel lain yang tidak ada dalam penelitian ini. 


\section{8 |Analisis Kualitas Layanan Mobile JKN Terhadap Kepuasan Peserta Badan Penyelenggara Jaminan Sosial (BPJS) Kesehatan}

\section{KESIMPULAN}

Berdasarkan data yang diperoleh dalam penelitian ini dan hasil penelitian mengenai pengaruh kualitas layanan Mobile JKN terhadap kepuasan peserta JKN-KIS Badan Penyelenggara Jaminan Sosial (BPJS) Kesehatan, maka dapat diambil kesimpulannya sebagai berikut: Variabel Reliability berpengaruh positif, namun tidak signifikan terhadap kepuasan peserta JKN-KIS BPJS Kesehatan. Variabel Efficiency berpengaruh positif dan signifikan terhadap kepuasan peserta JKN-KIS BPJS Kesehatan. Variabel fulfillment berpengaruh positif dan signifikan terhadap kepuasan peserta JKN-KIS BPJS Kesehatan. Variabel Privacy berpengaruh positif, namun tidak signifikan terhadap kepuasan peserta JKN-KIS BPJS Kesehatan. Variabel Responsiveness berpengaruh positif dan signifikan terhadap kepuasan peserta JKN-KIS BPJS Kesehatan. Variabel Contact berpengaruh positif, namun tidak signifikan terhadap kepuasan peserta JKN-KIS BPJS Kesehatan. Berdasarkan hasil Uji Simultan (Uji F) variabel reliability, efficiency, fulfillment, privacy, responsiveness, dan contact berpengaruh positif dan signifikan terhadap kepuasan peserta.

\section{DAFTAR PUSTAKA}

Akbar, M. M., \& Parvez, N. 2009. Impact of Service Quality, Trust, and Customer Satisfaction on Customers Loyalty. Abac Journal, 29(1), 24-38.

Asadpoor, S., \& Abolfazli, A. 2017. Effect of Electronic Service Quality on Customer Satisfaction and Loyalty Saderat Bank's Customers. International Journal of Scientific Study, 5(4), 407-411. Https://Doi.Org/10.17354/Ijssi/2017/56

BPJS Kesehatan. 2017. Akses Pelayanan dalam Genggaman BPJS Kesehatan Luncurkan Aplikasi Mobile JKN, Banyak Manfaat dan Kemudahan Peserta JKN-KIS. BPJSKesehatan.go.id.

Chesanti, P. C., \& Setyorini, R. 2017. Pengaruh E-Service Quality terhadap Kepuasan Pelanggan sebagai Pengguna Aplikasi PLN Mobile. Jurnal Penelitian Pendidikan, 1017.

Febrianta, A., \& Indrawati. 2016. Influence of Mobile Banking Service Quality to Customer Satisfaction Bank BCA In Bandung. E-Proceeding of Management, 3(3), 2879-2885.

Iswanca, R., Rachmawati, I., \& Prabowo, F. S. A. 2016. Pengaruh E-Service Quality Aplikasi Garuda Indonesia terhadap Customer Satisfaction Garuda Indonesia. E-Proceeding of Management, 3(3), 2781-2790.

Kesehatan, B. 2019. Jumlah Peserta JKN-KIS. Retrieved from Https://Www.BpjsKesehatan.Go.Id/Bpjs/

Kotler, P., \& Keller, K. L. 2009. Manajemen Pemasaran (Edisi 13). Jakarta: Erlangga. 
Parasuraman, A., Zeithaml, V. A., \& Malhotra, A. 2005. E-S-Qual: A Multiple-Item Scale for Assessing Electronic Service Quality. Journal of Service Research, 7 (X), 1-21. Https://Doi.Org/10.1177/1094670504271156

Safira, C. F., Kusyanti, A., \& Aryadita, H. 2017. Analisis Kualitas Layanan Website Bukalapak terhadap Kepuasan Pengguna Menggunakan E-S-Qual. Jurnal Pengembangan Teknologi Informasi dan Ilmu Komputer, 1(12), 1813-1821. Retrieved from Http://jptiik.ub.ac.id

Saleh, I. I. 2018. BPJS Kesehatan Sosialisasi Mobile JKN di Polda Metro Jaya. Http://M.Rri.Co.Id/Jakarta/Post/Berita/571728/Layanan_Publik/Bpjs_Kesehatan_ Sosialisasi_Aplikasi_Mobile_Jkn_Di_Polda_Metro_Jaya.Html

Tjiptono, F. 2000. Pemasaran Jasa. Yogyakarta: Andi ofst.

Tjiptono, F. 2014. Pemasaran Jasa - Prinsip, Penerapan, dan Penelitian. Yogyakarta: Andi.

Widiani, Y. N., \& Abdullah. 2018. Kualitas Pelayanan E-Government Melalui Aplikasi E-Filing Kantor Pelayanan Pajak Pratama Bandung Cibeunying terhadap Kepuasan Pengguna Aplikasi. Jurnal Riset Bisnis Dan Manajemen, 11(2), 38-46.

Wijiutami, S. S., \& Octavia, D. 2017. Pengaruh E-Service Quality terhadap E-Satisfaction serta Dampaknya pada E-Loyalty Pelanggan E- Commerce C2c di Kota Jakarta dan Bandung. E-Proceeding of Management, 4(3), 2212-2220.

Zeithaml, V. A., Parasuraman, A., \& Malhotra, A. 2002. Service Quality Delivery through Web Sites : A Critical Review of Extant Knowledge. Journal of the Academy of Marketing Science, 30(4), 362-375. https://doi.org/10.1177/009207002236911 